\title{
JORGE LUIS BORGES: ENIGMAS E LABIRINTOS LITERÁRIOS
}

Elo da Cunha Soares (UFMG)

Sem dúvidas, um dos grandes méritos de sua expressão literária é ter incorporado o leitor na obra. Autor, obra e leitor convivem em permanente metamorfose, possibilitando que cada texto, em face de diferentes leitores, adote diferentes versões, transformando nesse processo o próprio autor.

Alejandro Vaccaro

O sistema de funcionamento de toda língua pode se resumir na identificação de signos, significantes e significados. Sendo este processo tanto exterior como interior ao próprio homem, pois este faz uso da linguagem - e seu código: a língua. Assim, este sistema permite ao homem transformar conhecimento abstrato em reflexão; permitindo-lhe conceber uma representação qualquer, abstrata ou intuitiva, racional ou empírica.

Essa capacidade de representação inata ao ser humano tem entre seus expoentes a linguagem e, por conseqüência, a literatura. É por meio desta que pode subverter a lógica da linguagem, "trapacear com a língua, trapacear a língua. Essa trapaça salutar, essa esquiva, esse logro magnífico que permite ouvir a língua fora do poder, no esplendor de uma revolução permanente da linguagem". ${ }^{1}$ Pois a literatura permite a substituição da "realidade", enquanto referente da literatura, pela própria literatura.

Esta é a questão: uma simples letra - o nosso Aleph borgeano - pode carregar o potencial de representar todo o universo, percebido através dos olhos humanos - e de que outra forma poderia ser? - e vai além... poderia representar o ficcional, o não dito, o dito, o passado, a representação do futuro, do presente, do espaço e da relação entre o espaço e o tempo. Segundo Compagnon, "a teoria da literatura instituiu a autonomia da literatura em relação à realidade, ao mundo, e

\footnotetext{
${ }^{1}$ BARTHES, 1978, p. 16.
} 
defendeu a tese do primado da forma sobre o fundo, da expressão sobre o conteúdo, do significante sobre o significado."2

Tomemos a idéia primeira de que "a relação lingüística primária não estabeleça mais uma relação entre a palavra e a coisa, ou o signo e o referente, o texto e o mundo, mas entre um signo e outro signo, um texto e outro texto."’3 Assim, tudo o que resta verificar são as relações de comparação e de compartilhamento de signos, idéias, conceitos e textos. Tratemos de intertextualidade como referência explícita que substitui o lugar da realidade. "A intertextualidade está pois calçada naquilo que Bakhtin chama de dialogismo, isto é, nas relações que todo o enunciado mantém com os outros enunciados". 4

Assim como todos os textos seriam compartilhados e sofreriam um processo de eterna referenciação, como Borges nos sugere na "Biblioteca de Babel", o mesmo aconteceria com as idéias. Se podemos chegar a um só exemplar - livro que possa conter todo o conhecimento compartilhado pela humanidade, assim também poderíamos fazer com as idéias e com a própria concepção de homem. Podendo um só homem ser representante de toda uma humanidade.

Para Borges, a literatura parece ser única e os autores seriam apenas traços distintivos que permitem às idéias meterializarem-se de modo diferenciado, retornando sempre a uma concepção pré-existente, imemorável, em um eterno regressus ad infinitum, em busca de um início onde toda a arte é compartilhada:

Para mentes clássicas, a literatura é o essencial, não os indivíduos. George Moore e James Joyce incorporaram, em suas páginas, páginas de sentenças alheias; Oscar Wilde costumava dar seus argumentos de presente para que outros os executassem; ambas as condutas, embora superficialmente opostas, podem evidenciar um mesmo sentido da arte, Um sentido ecumênico, impessoal...5

Essa passagem, retirada do conto "A flor de Coleridge", nos remete à concepção borgeana de uma literatura universal, na qual os argumentos estariam

\footnotetext{
${ }^{2}$ COMPAGNON, 1999, p. 96 - 97.

${ }^{3}$ COMPAGNON, 1999, p. 105.

${ }^{4}$ COMPAGNON, 1999, p. 111.

${ }^{5}$ BORGES, Obras Completas, II, 1995, p. 18.
} 
disponíveis para qualquer um que queira trabalhá-los. Apresentando ainda, ao final do conto, a idéia de que a literatura não está em um homem, ou autor, mas no conjunto de autores que alimentam a capacidade imaginativa de seu leitor.

A escrita de Borges é permeada de elementos que nos levam a perceber a universalidade das idéias. As representações ausentes de significados absolutos e a escrita labiríntica fazem de sua obra uma fonte constante de novas observações. A estratégia de escrita de atribuir a autoria de seus textos a outros autores envolve o leitor numa teia, gerando um simulacro de realidade. Não se trata de imitação ou ilusão sobre o mundo real, mas uma ilusão do discurso verdadeiro sobre o mundo real ou sobre o próprio discurso.

Podemos perceber, na escrita de Borges, o potencial da palavra, assim como o poder de sua menor unidade: a letra. O universo maravilhoso da literatura borgeana nos faz, por diversas vezes, repensar esta idéia: a de que uma simples palavra, ou um simples conceito, pode ser superior à concepção de tempo e espaço, ou mesmo à idéia de materialidade. A Biblioteca de Babel, detentora de todo o conhecimento humano, repleta de segredos, obscuridades e labirintos de conhecimento, pode nos ser apresentada em um único volume, ou mesmo em uma única letra: o Aleph. Assim como a diversidade humana, todos os tipos ou situações de suas vivências podem ser representados pela existência de um único indivíduo. Para Canto,

Borges insistiu em quase todos os seus contos, em seus poemas, até em algumas entrevistas deturpadas - como são a maioria - que um homem é "todos os homens". Ou seja, o homem encerra em si mesmo todas as possibilidades: o homem é o microcosmo. ${ }^{6}$

O escritor argentino joga com suas tortuosas citações, seus caminhos bifurcados e imensos labirintos. Para ele, a palavra é conceito, símbolo e representação latentes à figura humana. As idéias são universais, atemporais; canalizadas, porém, pela capacidade de interpretação de cada indivíduo. Essa

\footnotetext{
${ }^{6}$ CANTO, 1991, p. 13.
} 
concepção nos leva à possibilidade de subverter os conceitos de plágio e de autoria e a ingressar no poderoso efeito lúdico desse autor.

Dos contos escritos por Borges dois destacam-se no que diz respeito ao processo da escrita e da construção da própria ficção, correlacionando autor, leitor e obra: "Pierre de Menard, autor do Quixote" e "A Biblioteca de Babel". O que nos leva à necessidade de realizar um breve comentário sobre ambos.

O conto "Pierre Menard, autor do Quixote" nos apresenta um questionamento acerca da questão da autoria, refletindo sobre a importância do autor e do compartilhamento de idéias, explicitando a existência de lacunas diversas a serem preenchidas no sistema de interpretações que é a literatura. Esse conto nos remete às mais profundas interligações e relações estabelecidas entre autor e leitor, realçando a possibilidade desse leitor vir a tornar-se, também, autor, o que nos levaria a uma estrutura cíclica. Nesse conto um segundo escritor propõe-se a reescrever a obra de Miguel de Cervantes, Dom Quixote, trezentos anos depois do autor original. E realmente o faz. Mas o conflito do conto apresenta-se: "O texto de Cervantes e o de Menard são verbalmente idênticos, mas o segundo é quase infinitamente mais rico. (Mais ambíguo, dirão seus detratores; mas a ambigüidade é uma riqueza)"”. Santiago nos elucida esta comparação entre esses autores de uma mesma obra:

No projeto de Pierre Menard o modelo e o decalque são idênticos, tornando a sua versão do Don Quijote diferente das suas produções anteriores onde sempre acrescentava semelhanças. O narrador do conto - e esta seria a razão de sua escrita - nos propõe então uma nova catalogação da obra global de Pierre de Menard, sob duas rubricas: levar-se-iam em conta o seu aspecto visível, e por outro lado o seu aspecto invisível. Este seria determinante da sua obra interminavelmente heróica, da sua obra "impar".

Segundo Monegal, nosso narrador borgeano reflete que "é lícito ver no Quixote 'final' uma espécie de palimpsesto, ${ }^{9}$ no qual devem transluzir os rastros -

\footnotetext{
${ }^{7}$ BORGES, 1986, p. 36.

${ }^{8}$ SANTIAGO, 1978, p. 52.

${ }^{9}$ Antigo material de escrita, principalmente o pergaminho, usado, em razão de sua escassez ou alto preço, duas ou três vezes. Manuscrito sob cujo texto se descobre outro, com o uso de técnicas especiais.
} 
tênues mas não indecifráveis - da 'prévia' escrita de nosso amigo"10 - Pierre Menard. Como se, na verdade, abaixo dos originais de Cervantes estivessem os rascunhos de Menard. Como se fosse possível ao primeiro ter acesso ao texto do segundo, apesar dos séculos que os separam. Como se todo homem fosse capaz de todas as idéias, num contexto de universalidade que nos é também apresentado em outro conto presente em Fiç̧ôes: "A Biblioteca de Babel”.

Nesse conto o escritor nos apresenta uma gigantesca biblioteca que promete ser a representação do próprio universo, onde estão inseridos livros de tamanhos, formatos e quantidades de letras exatos, iguais e pré-determinados, onde repetemse, aleatoriamente, os vinte e cinco signos gráficos que compõem a escrita humana - o ponto, a virgula, o espaço e as vinte e duas letras do alfabeto - , e que, se combinados, podem gerar significados distintos que nos permitam a representação de qualquer conceito ou objeto em qualquer idioma.

Não que a biblioteca não tenha previsto e que nalguma de suas línguas secretas não contenham um terrível sentido. Ninguém pode articular uma sílaba que não esteja cheia de ternura e de temores; que não seja nalguma dessas linguagens o nome poderoso de um deus. Falar é incorrer em tautologias. ${ }^{11}$

A idealização máxima para a existência dessa biblioteca seria a figura de um livro que abarcasse a versão de todos os livros em todas as línguas, as intercalações de cada livro em todos os livros. Idéia muito próxima do pensamento de Foucault:

O livro não é mais o espaço onde a palavra adquire figura (figuras de estilo, de retórica e de linguagem), mas o lugar onde os livros são retomados e consumidos: lugar sem lugar, pois abriga todos os livros passados neste impossível 'volume', que vem colocar seu murmúrio entre tantos outros - após todos os outros, antes de todos os outros. ${ }^{12}$

Essa mesma concepção nos demonstraria como a vastidão dessa biblioteca pode ser traduzida; como poderia ser compilada em um só volume, onde cada folha se desdobrasse em outra e essa em outra e se torna um grande livro circular de

\footnotetext{
${ }^{10}$ MONEGAL, 1980, p. 125.

${ }^{11}$ BORGES, 1986, p. 21.

${ }^{12}$ FOUCAUT, 2001, p. XII.
} 
lombada contínua, o catálogo dos catálogos, a expressão idealizada do próprio criador da biblioteca, a manifestação máxima da existência de um criador, e, para Borges, o bibliotecário que o consultasse seria análogo a um deus.

Borges nos demonstra, por meio da metáfora da biblioteca, a característica unificante da própria literatura. Onde os escritores seriam apenas bibliotecários a consultar volumes e a construir situações possíveis de enredos já universalizados. Como se a idéia de plágio ou cópia apenas nos fizesse compreender a concepção de realidade compartilhada, e porque não, de literatura compartilhada. $\mathrm{Na}$ qual o autor seria apenas o catalisador desses milhões de eventos ficcionais ou apenas mais um barqueiro na imensidão de um oceano literário. Temos que, para Borges, o mundo pode ser representado por uma "combinatória finita", 13 mas que a literatura e sua realização maior, a recepção desta pelo leitor, pode possuir significados infinitos.

Para Borges o sujeito é múltiplo, o ser é múltiplo, o autor é múltiplo enquanto desdobra-se no "outro": o narrador, ou o personagem em que se metamorfoseia. Essa multiplicidade, esse compartilhamento de informações é que, paradoxalmente, faz com que se possa construir o conceito de realidade compartilhada. Uma vez que o leitor, ao compartilhar com o autor a construção da obra torna-se, também, "um duplo inseparável e não antagônico, do autor. Tal qual o autor, o leitor é ficção. O livro vira diálogo uma vez que os pares de produção e recepção são complementares". ${ }^{14}$

Ao atribuir a autores falsos a autoria de seus textos, ao inserir-se enquanto personagens de alguns destes ou quando copia abertamente argumentos de outros escritores - até os cita ou insere como personagens - Borges funda uma nova concepção de literatura. Como conseqüência, estabelece uma nova interpretação para a concepção de autoria. Trata-se de uma nova ficção, como ressalta Costa Lima:

Esta ficção não remete, sequer como instância mediatizada, a formas de existência, mas sim a um encaixe de ficções, livros dentro

\footnotetext{
${ }^{13}$ LIMA, 1980, p. 242.

${ }^{14}$ SEDLMEYER, 2001, p. 134.
} 
de livros, comentários ficcionais a textos também ficcionais, onde figuras muitas vezes reais, autores e amigos, remetem diálogos ficcionais e relatos ficcionais fingem ser relatos do real. ${ }^{15}$

Faz-se necessária a percepção de uma literatura especular, que promova uma dobra sobre si, refletindo e buscando a reflexão através do receptor. Jorge Luis Borges escreve textos baseados em outros textos e escritos por outras mãos. Se existe um grande labirinto em sua literatura, é o labirinto das idéias. Seus caminhos bifurcados nos fazem revolver a memória e acabam nos conduzindo a um só lugar: o próprio texto borgeano. Lugar único, mas ambivalente, onde, juntos, leitor e autor podem construir um significado também único e pessoal, mas que possibilita ao labirinto, ou à malha de significação, anexar mais um caminho possível, mais uma compreensão ímpar, que, somada às outras muitas, possa encerrar-se nas prateleiras da Biblioteca de Babel e na constituição de uma identidade universal.

\section{Referências Bibliográficas}

VACCARO, Alejandro. Borges: uma biografia em imagens. São Paulo: Planeta, 2006.

BARTHES, Roland. Aula. São Paulo: Ed. Cultrix, 1978.

BORGES, Jorge Luis. Obras Completas II. São Paulo: Editora Globo, 1995

BORGES, Jorge Luis. Fiçcões. Rio de Janeiro: Ed Globo. 1986

CANTO, Estela. Borges à contralu₹: São Paulo: Iluminuras, 1991

COMPAGNON, Antoine. O demônio da teoria: literatura e senso comum. Trad. Cleonice Paes Barreto Mourão. Belo Horizonte: Editora UFMG, 1999.

FOUCAULT, Michel. Estética: Literatura e Pintura, Música e Cinema. Rio de Janeiro: Forense Universitária, 2001.

LIMA, Luis Costa. Mimesis e modernidade: formas das sombras. Rio de Janeiro: Edições Graal Ltda, 1980.

MONEGAL, Emir Rodriguez. Borges: uma poética da Leitura. São Paulo: Perspectiva, 1980.

$15 \quad$ LIMA. 1980. p. 241. 
SEDLMAYER, Sabrina. Quanto a mim, eu: subjetividade literária em Pessoa e Borges. 2001. Tese (Doutorado em Literatura) - Faculdade de Letras da UFMG, Belo Horizonte.

SANTIAGO, Silviano. Uma Literatura nos Trópicos: Ensaios sobre dependência cultural. Perspectiva: São Paulo, 1978. 